\title{
A passion for the profession How ACRL benefits you
}

A CRL strives to position academic and research libraries and librarians as indispensable to advancing learning and transforming scholarship. Academic and research librarians believe in the power of academic and research libraries to transform lives, and ACRL is dedicated to helping members become flexible, dynamic, and entrepreneurial leaders in their institutions and scholarly communities.

Each year we interview 52 ACRL members to discover why they value the profession and the association. Start your week by visiting the ACRL Insider blog (www. acrl.ala.org/acrlinsider/archives/category /member-of-the-week) for a fresh perspective on the value of academic and research librarianship and ACRL membership.

\section{The network that works}

More than 11,000 engaged academic and research librarians call ACRL home. Why? ACRL brings talented and highly motivated members together by providing strategic connections to colleagues, opportunities, and resources.

As one member stated, "Through my participation in ACRL, I have developed a network of colleagues across the country that share similar goals, face similar challenges, and are willing to engage in sharing the work of addressing the issues facing our profession. ACRL has always been my professional 'home."'

ACRL is a lifeline to the academic and research library community offering com- munities of practice, discussion lists, biennial conferences, and publications. The sharing of experience and expertise among members creates a vibrant environment that facilitates networking and collaboration.

"At my first ACRL conference I was truly impressed by the number of colleagues who are so passionate and so committed to improving the education experience for the students on their campus. It was inspiring."

\section{Strengthen your professionalism}

ACRL is a leading provider of professional development for academic and research librarians. Through professional development programs, conferences, publications, e-learning, discussion lists, and committee service, ACRL provides a supportive infrastructure that allows each member to achieve a high level of continuous learning. "ACRL provides vital opportunities for librarians to expand their professional knowledge by learning from colleagues' successes."

Advancement opportunities include research, publication, teaching, and service. Members value the growth and leadership opportunities provided by ACRL. Our publications, including CERL News, CERL, Choice, books, standards, and blogs, allow members to keep up with (and advance) the field. Our governance structure provides opportunities to lead, create, and shape the profession. In

Mary Jane Petrowski is ACRL associate director, e-mail: mpetrowski@ala.org

() 2012 Mary Jane Petrowski 
short, "ACRL makes me think critically and creatively about contributions I can make to the field."

ACRL is also dedicated to developing members who are recognized as leaders in their institutions and in scholarly communities. ACRL members leverage their new connections and learning opportunities to enhance and support the services and collections for which they are responsible. Institutional enhancement represents the ultimate return on your membership investment: "ACRL membership is not just for you but for your library."

\section{Enhancing theory (and practice)}

As a leading publisher of research and practice that advances the field with guidelines, standards, research, statistics, and toolkits, ACRL keeps members abreast of issues, trends, and effective practices. "ACRL is a vibrant avenue to information in our profession."

As one member noted, "While pursuing my MLIS (and now into my professional career), I read College and Research Libraries News and College and Research Libraries to stay current with new ideas in the field of librarianship. I often use these publications to connect with others and inform the services I provide."

\section{ACRL: Leading the profession}

ACRL membership demonstrates solidarity and support for work that ACRL does to tackle the critical issues facing academic and research librarians. "I appreciate ACRL's advocacy for the value of libraries and librarians within the higher education environment."

Join today and become part of a "lifechanging organization," a passionate community of academic and research librarians who are dedicated to the profession and willing to share their wisdom and experience. Membership application forms are available online at www.acrl.org. $n$

\section{Why "really smart librarians" belong to ACRL}

“ACRL provides so many opportunities for academic librarians to learn, to network, to stretch their thinking and to push boundaries. If ACRL didn't exist, we'd have to create it."-Paula T. Kaufman, Juanita J. and Robert E. Simpson dean of libraries and university librarian, the University of Illinois at UrbanaChampaign

"My affiliation with ACRL has had a phenomenal impact on the course of my career. I can't envisage what our field would be like were there no ACRL."-Trudi Jacobson, distinguished librarian and head of the information literacy department, University at Albany-SUNY

"The ACRL Immersion program made me a better teacher, the publications and initiatives make me more thoughtful about my work, and the conferences invigorate me with new ideas and camaraderie."-John Watts, instruction and liaison services librarian, Webster University

"ACRL is the one organization that's focused on precisely where I put my energy and attention: academic librarianship. The resources that ACRL dedicates to connecting academic librarians to each other and to big ideas about our shared profession are invaluable. The organization, as a powerful presence for many librarians, draws attention to undervalued areas of our profession, highlights issues that we should be aware of, and connects thinkers to doers in ways we cannot do alone."-Jenica P. Rogers, director of libraries, State University of New York-Potsdam

"ACRL provokes me. ACRL disrupts me. All in the best way possible: ACRL challenges me to think more broadly and to consider new perspectives." - Michael Ridley, librarian, University of Guelph

"Where else can you find a new job, discover continuing education opportunities, get the latest standards of practice, and read the latest news and professional literature? That's ACRL!"-Richard Kaplan, dean of library and learning resources, Massachusetts College of Pharmacy and Health Sciences 